\title{
SISTEM PENGELOLAAN BADAN PENYELENGGARA JAMINAN SOSIAL (BPJS) KESEHATAN MANDIRI KOTA PAREPARE (ANALISISN HUKUM EKONOMI ISLAM)
}

\author{
Syahriyah Semaun \\ Institut Agama Islam Negeri (IAIN) Parepare \\ syahriyah.semaun@gmail.com \\ Juneda \\ Institut Agama Islam Negeri (IAIN) Parepare \\ junedanurdin@gmail.com
}

\begin{abstract}
Law Number 40 of 2004 concerning the National Social Security System (SJSN) mandates that social security is mandatory for all residents including the National Health Insurance (JKN) through a Health Social Security Administering Agency (BPJS). This study discusses how the contract system in the Mandiri Health BPJS, how the mechanism for collecting contributions to the Mandiri Health BPJS, and how the quality of BPJS Health guarantees in Parepare City for health services for Mandiri Health BPJS participants. This study included a qualitative descriptive study with an analysis of Islamic economic law in the Office of BPJS Health in the City of Parepare. The results of the study indicate that the contract system in the Independent Health BPJS in the City of Parepare is in accordance with Islamic economic law and the mechanism for collecting contributions from Mandiri Health BPJS participants is not in accordance with Islamic economic principles. Quality assurance of BPJS Kesehatan in the City of Parepare for health services participants of the Independent Health BPJS in accordance with Islamic econc law.
\end{abstract}

Key Word: Mandiri Health BPJS, contract, contribution, quality of health insurance, Islamic Economic Law.

Abstrak: Undang-Undang Nomor 40 Tahun 2004 tentang Sistem Jaminan Sosial Nasional (SJSN) yang mengamanatkan bahwa jaminan sosial wajib bagi seluruh penduduk termasuk Jaminan Kesehatan Nasional (JKN) melalui suatu Badan Penyelenggara Jaminan Sosial (BPJS) Kesehatan. Penelitian ini membahas bagaimana sistem akad pada BPJS Kesehatan Mandiri, bagaimana mekanisme pengumpulan iuran pada BPJS Kesehatan Mandiri, dan bagaimana mutu jaminan BPJS Kesehatan di Kota Parepare terhadap pelayanan kesehatan bagi peserta BPJS Kesehatan Mandiri. Penelitian ini termasuk penelitian deskriptif kualitatif, dengan analisis hukum ekonomi Islam di Kantor BPJS Kesehatan Kota Parepare.

Hasil penelitian menunjukkan bahwa sistem akad pada BPJS Kesehatan Mandiri di Kota Parepare sudah sesuai dengan hukum ekonomi Islam dan Meknisme pengumpulan iuran peserta BPJS Kesehatan Mandiri belum sesuai dengan prinsip ekonomi Islam. Mutu jaminan BPJS Kesehatan di Kota Parepare terhadap pelayanan kesehatan bagi peserta BPJS Kesehatan Mandiri sudah sesuai dengan hukum 
285 | Diktum: Jurnal Syari'ah dan Hukum, Volume 16, Nomor 2 Desember 2018 : 284 - 306

ekonomi Islam.

Kata Kunci: BPJS Kesehatan Mandiri, akad, iuran, mutu jaminan kesehatan, Hukum Ekonomi Islam.

\section{PENDAHULUAN}

\subsection{Latar Belakang Masalah}

Hak tingkat hidup yang memadai untuk kesehatan dan kesejahteraan diri dan keluarga merupakan hak asasi manusia dan diakui oleh segenap bangsa-bangsa di dunia, termasuk Indonesia. Di Indonesia, falsafah dan dasar negara Pancasila terutama sila ke-5 juga mengakui hak asasi warga atas kesehatan. Hak ini juga termaktub dalam Undang-Undang Dasar 1945 pasal $28 \mathrm{H}$ dan pasal 34 , dan diatur dalam Undang-Undang Nomor 23 Tahun 1992 tentang Kesehatan yang kemudian diganti dengan UndangUndang Nomor 36 Tahun 2009 tentang Kesehatan. Dalam Undang-Undang Nomor 36 Tahun 2009 tentang Kesehatan ditegaskan bahwa setiap orang mempunyai hak yang sama dalam memperoleh akses atas sumber daya di bidang kesehatan dan memperoleh pelayanan kesehatan yang aman, bermutu, dan terjangkau. Sebaliknya, setiap orang juga mempunyai kewajiban turut serta dalam program jaminan kesehatan sosial.

Untuk mewujudkan konstitusi di atas, pemerintah Indonesia bertanggung jawab atas pelaksanaan jaminan kesehatan masyarakat melalui Jaminan Kesehatan Nasional (JKN). Dengan dikeluarkannya UndangUndang Nomor 40 Tahun 2004 tentang Sistem Jaminan Sosial Nasional (SJSN) yang mengamanatkan bahwa jaminan sosial wajib bagi seluruh penduduk termasuk Jaminan Kesehatan Nasional (JKN) melalı . suatu Badan Penyelenggara Jaminan Sosial (BPJS).

Undang-Undang Nomor 24 Tahun 2011 tentang Badan Penyelenggara Jaminan Sosial juga menetapkan, Jaminan Sosial Nasional akan diselenggarakan oleh BPJS, yang 
285 | Diktum: Jurnal Syari'ah dan Hukum, Volume 16, Nomor 2 Desember 2018 : 284 - 306

terdiri atas BPJS Kesehatan dan BPJS

Ketenagakerjaan. Khusus untuk Jaminan Kesehatan Nasional (JKN) akan diselenggarakan oleh BPJS Kesehatan yang implementasinya dimulai 1 Januari 2014. Dimana, BPJS Kesehatan merupakan badan hukum yang dibentuk untuk penyelenggarakan program jaminan kesehatan.

Secara

operasional, pelaksanaan JKN dituangkan dalam Peraturan Menteri Kesehatan Republik Indonesia Nomor 4 Tahun 2017 Tentang Perubahan Kedua Atas Peraturan Menteri Kesehatan Nomor 52 Tahun 2016 Tentang Standar Tarif Pelayanan Kesehatan dan Peraturan Presiden Republik Indonesia Nomor 28 Tahun 2016 tentang Perubahan Ketiga Atas Peraturan Presiden Nomor 12 Tahun 2013 tentang Jaminan Kesehatan. ${ }^{1}$

Jaminan Kesehatan Nasional (JKN) yang dikembangkan di Indonesia merupakan bagian dari Sistem Jaminan Sosial Nasional (SJSN). Sistem Jaminan Sosial
Nasional ini diselenggarakan melalui mekanisme asuransi kesehatan sosial yang bersifat wajib (mandatory) berdasarkan Undang-Undang Nomor 40 Tahun 2004 tentang Sistem Jaminan Sosial Nasional. Tujuannya adalah agar semua penduduk Indonesia terlindungi dalam sistem asuransi, sehingga mereka dapat memenuhi kebutuhan dasar kesehatan masyarakat yang layak. $^{2}$

Berdasarkan kaidah muamalah, siapa saja boleh dan bebas membuat akad jenis apapun tanpa terikat dengan nama-nama akad yang sudah ada dan memasukkan klausul apa saja sejauh tidak berakibat memakan harta sesama dengan jalan yang batil atau tidak bertentangan dengan asas yang lain, upaya ini dilakukan sebagai bagian dari proses mengurangi risiko terjadinya pelanggaran atas ketentuan syariah.

Karena itu, pelaksanaan JKN diselenggarakan secara nasional berdasarkan prinsip asuransi sosial dan prinsip ekuitas. Prinsip asuransi sosial adalah sistem pengumpulan dana 
bersifat wajib berasal dari iuran guna memberikan perlindungan atas risiko sosial ekonomi yang menimpa peserta dan atau anggota keluarganya. Adapun yang dimaksud dengan prinsip ekuitas adalah tiap peserta yang membayar iuran akan mendapat pelayanan kesehatan sebanding dengan iuran yang dibayarkannya. ${ }^{3}$

Berdasarkan prinsip ekuitas itulah sehingga terdapat pembagian atau penggolongan dalam kepesertaan BPJS Kesehatan menjadi 2 bagian yaitu: Peserta PBI Jaminan Kesehatan dan peserta bukan PBI Jaminan Kesehatan. Peserta PBI Jaminan Kesehatan merupakan fakir miskin dan orang tidak mampu sebagai peserta jaminan kesehatan yang di daftarkan oleh pemerintah dan iurannya dibayarkan oleh pemerintah. Sedangkan peserta bukan PBI Jaminan Kesehatan merupakan Peserta yang tidak tergolong fakir miskin dan orang tidak mampu yang terdiri atas: pekerja penerima upah dan anggota keluarganya; pekerja bukan penerima upah dan anggota keluarganya; dan bukan pekerja dan anggota keluarganya.

Golongan BPJS peserta bukan PBI Jaminan Kesehatan inilah yang selanjutnya disebut sebagai BPJS Kesehatan Mandiri, karena pesertanya membayarkan secara mandiri iuran Jaminan Kesehatan kepada BPJS Kesehatan. Baik itu iuran Jaminan Kesehatan bagi peserta pekerja penerima upah yang dibayarkan oleh pemberi kerja dan pekerja, maupun iuran Jaminan Kesehatan bagi peserta pekerja bukan penerima upah dan peserta bukan pekerja yang dibayarkan oleh peserta atau pihak lain atas nama peserta. $^{4}$

Tujuan dari Jaminan Kesehatan Nasional (JKN) yang diselenggarakan oleh BPJS Kesehatan ini berdasarkan Undang-Undang Nomor 40 Tahun 2004 tentang Sistem Jaminan Sosial Nasional adalah agar semua penduduk Indonesia terlindungi dalam sistem asuransi, sehingga mereka dapat memenuhi kebutuhan dasar kesehatan masyarakat yang layak.

Akan tetapi di Indonesia, dimana mayoritas masyarakatnya beragama Islam, merasa bimbang 
287 | Diktum: Jurnal Syari'ah dan Hukum, Volume 16, Nomor 2 Desember 2018 : 284 - 306

terhadap kewajiban mengikuti dan menjadi peserta Jaminan Kesehatan Nasional (JKN) yang diselenggarakan oleh BPJS Kesehatan. Hal ini disebabkan karena adanya Keputusan Komisi B 2 Masail Fiqhiyyah Mu'ashirah (Masalah Fikih Kontemporer) Ijtima' Ulama Komisi Fatwa Se-Indonesia V Tahun 2015 Tentang Panduan Jaminan Kesehatan Nasional dan BPJS Kesehatan.

Selain itu terdapat beberapa permasalahan yang muncul berkaitan dengan BPJS Kesehatan ini, dan menjadi masalah yang diangkat oleh penyusun sebagai topik pembahasan dalam penelitian yang akan disusun seperti:

\subsubsection{Sejak BPJS Kesehatan ini} ditetapkan dan beroperasi seperti perusahaan asuransi, dimana semua rakyat Indonesia diwajibkan bergabung dan harus membayar iuran rutin yang masuk ke rekening BPJS Kesehatan.

\subsubsection{Ketika terjadi keterlambatan pembayaran iuran maka}

peserta BPJS Kesehatan Mandiri akan dikenakan sanksi. 1.1.3 Keluhan peserta terhadap layanan kesehatan di rumah sakit yang diberikan kepada peserta BPJS Kesehatan Mandiri berdasarkan golongangolongan yang telah dibayarkan iurannya, terkadang tidak sesuai dengan harapan peserta BPJS Kesehatan Mandiri.

\subsection{Rumusan Masalah}

Berdasarkan latar belakang yang telah diuraikan di atas, apabila di analisis secara Hukum Ekonomi Islam maka dapat dirumuskan beberapa masalah antara lain:

1.2.1 Bagaimana sistem akad pada BPJS Kesehatan Mandiri di Kota Parepare?

1.2.2 Bagaimana mekanisme pengumpulan iuran pada BPJS Kesehatan Mandiri di Kota Parepare?

1.2.3 Bagaimana mutu jaminan BPJS Kesehatan di Kota Parepare terhadap pelayanan kesehatan 
bagi peserta BPJS Kesehatan Mandiri?

\section{A. TINJAUAN PUSTAKA}

\subsection{Tinjauan Teoritis}

\subsubsection{Teori Sistem}

Teori sistem yang pertama kali diuraikan oleh Kenneth Boulding terutama menekankan pentingnya perhatian terhadap setiap bagian yang membentuk sebuah sistem, kecenderungan manusia yang mendapat tugas memimpin suatu organisasi adalah bahwa dia terlalu memusatkan perhatian kepada salah satu komponen saja dari sistem organisasi. Teori sistem mengatakan bahwa setiap unsur pembentuk organisasi adalah penting dan harus mendapat perhatian yang utuh supaya manajer dapat bertindak lebih efektif.

\subsubsection{Pengelolaan}

$$
\text { Pengelolaan adalah }
$$

penyelenggaraan, pengurus atau proses yang membantu merumuskan kebijaksanaan dan tujuan organisasi. Pengelolaan sama halnya dengan manajemen, karena pengelolaan dalam sebuah organisasi memerlukan pelaksanaan tanggung jawab manajerial secara terus menerus. Dan tanggung jawab tersebut secara kolektif sering disebut sebagai fungsi manajemen.

Manajemen dalam organisasi pada dasarnya di maksudkan sebagai suatu proses (aktivitas) penentuan dan pencapaian tujuan melalui pelaksanaan empat fungsi dasar : Planning, organizing, actuating dan controlling dalam penggunaan sumber daya organisasi, manajemen memerlukan koordinasi sumber daya manusia dan material ke arah tercapainya tujuan. Untuk memperjelas arti manajemen, di bawah kutipan pendapat beberapa pakar di bidang manajemen antara lain:

Manajemen menurut G. R. Terry dalam bukunya principles of management, merupakan suatu proses yang khas yang terdiri dari tindakantindakan dan pengendalian yang dilakukan untuk menentukan serta mencapai sasaran-sasaran yang telah ditentukan melalui pemanfaatan sumber daya manusia dan sumbersumber lainnya.

2.2.3 Pengertian Akad 
289 | Diktum: Jurnal Syari'ah dan Hukum, Volume 16, Nomor 2 Desember 2018 : 284 - 306

Secara etimologi, akad berasal dari bahasa Arab yaitu عَقَدَ- يَعْقِدُ- عَقْدَا yang berarti persetujuan, perikatan, perjanjian, dan pemufakatan (alittifaq). ${ }^{5}$ Akad juga dapat berarti perjanjian (آلَعْهُُو), karena pelaku akad saling berjanji untuk mematuhi dan melaksanakan apa-apa yang telah dibuat dan disepakati bersama. Adapun secara terminologi, akad didefinisikan sebagai ikatan ijab (pernyataan melakukan ikatan) dan qabul (pernyataan penerimaan ikatan) yang dibenarkan oleh syara', menetapkan kerelaan antara dua pihak yang melakukan akad dan berdampak pada objek akad. ${ }^{6}$ Yang dimaksud sesuai dengan kehendak syariat yang berpengaruh pada obyek perikatan ${ }^{7}$ adalah bahwa seluruh perikatan yang dilakukan tidak boleh bertentangan dengan ketentuan syariat (Al-Qur'an dan Hadis). ${ }^{8}$

Menurut Abdulahanaa yang mengutip pendapat Mustafa Ahmad azZarqa, suatu akad merupakan tindakan hukum (ikatan secara hukum) yang dilakukan oleh dua atau beberapa pihak yang sama-sama berkeinginan mengikatkan diri. Dengan demikian, pihak yang menyalahi atau tidak mematuhi apa yang telah diakadkan maka dengan sendirinya berkewajiban menanggung sanksi. Bentuk sanksi yang wajib ditanggung ada tiga kemungkinan: pertama, sesuai dengan isi perjanjian, jika pada waktu melakukan akad ditentukan jenis sanksi yang diancamkan. Kedua, jika jenis sanksi tidak disebutkan dalam akad, maka bentuk sanksinya kembali kepada ketentuan-ketentuan dasar yang berlaku umum sebagaimana dalam dalil nash atau hukum adat/ kebiasaan. Ketiga, jika tidak ada dalil atau ketentuan dasar/ umum yang mengaturnya, maka merujuk pada putusan hakim atau pihak pemegang otoritas dalam penyelesaian perkara/ sengketa.

\subsubsection{Teori premi/ iuran}

Premi adalah sejumlah uang yang dibayarkan oleh seseorang pemegang polis kepada perusahaan asuransi sehubungan dengan adanya 
perjanjian pertanggungan yang dituangkan dalam polis asuransi.

Premi dalam BPJS Kesehatan disebut sebagai iuran. Dimana iuran jaminan kesehatan ini adalah sejumlah uang yang dibayar secara teratur oleh peserta, pemberi kerja, dan/atau pemerintah untuk program jaminan kesehatan. Iuran kepesertaan jaminan kesehatan ini wajib dibayarkan oleh setiap peserta program Jaminan Kesehatan. Iuran tersebut harus dibayarkan paling lambat tanggal 10 (sepuluh) setiap bulannya pada bank yang telah bekerjasama dengan BPJS Kesehatan. Besaran iuran jaminan kesehatan bagi peserta jaminan kesehatan sesuai dengan ketentuan Peraturan Perundang-Undangan. ${ }^{9}$

Besaran iuran BPJS mandiri sewaktu-waktu dapat berubah sesuai dengan peraturan yang mengaturnya. Seperti peraturan yang berlaku hingga sekarang adalah Peraturan Presiden Nomor 19 Tahun 2016 tentang Perubahan Kedua atas Peraturan Presiden Nomor 12 Tahun 2013 Tentang Jaminan Kesehatan.

\subsubsection{Asuransi syariah}

2.2.4.1 Pengertian Asuransi Syariah Menurut Muhammad Syakir Sula yang dikutip dari Al-Fanjari mengartikan tadhamin, takaful, atta'min atau asuransi syariah dengan pengertian saling menanggung atau tanggungjawab sosial. ${ }^{10}$

Dewan Syariah Nasioanl Majelis Ulama Indonesia (DSN-MUI) dalam fatwanya tentang pedoman umum asuransi syariah, memberi definisi tentang asuransi syariah. Menurutnya, asuransi syariah (ta'min, takaful, tadhamun) adalah usaha saling melindungi dan tolong-menolong diantara sejumlah orang/ pihak melalui investasi dalam bentuk asset dan atau tabarru' yang memberikan pola pengembalian untuk menghadapi resiko tertentu melalui akad (perikatan) yang sesuai dengan syariah.

Akad takafuli dalam perusahaan asuransi syariah terdiri dari akad tabarru' dan akad tijari, dengan menggunakan prinsip mudharabah dan prinsip tabarru'. Akad tabarru' untuk kepentingan sosial, bukan untuk mencari keuntungan dan bersifat social oriented (hibah/charity), sedangkan 
291 | Diktum: Jurnal Syari'ah dan Hukum, Volume 16, Nomor 2 Desember 2018 : 284 - 306

akad tijari untuk kepentingan komersial/bisnis, bertujuan mencari keuntungan dan bersifat profit oriented.

\section{B. METODE PENELITIAN}

Adapun jenis penelitian yang digunakan adalah deskriptif kualitatif dengan pendekatan fenomenalogis. Tujuan dari penelitian ini adalah mengungkap fakta, keadaan, dan fenomena, yang terjadi saat penelitian berjalan dan menyuguhkan apa adanya. Penelitian deskriptif kualitatif menafsirkan dan menuturkan data yang bersangkutan dengan situasi yang sedang terjadi, sikap serta pandangan yang terjadi di dalam masyarakat, pertentangan dua keadaan atau lebih, perbedaan antar fakta, dan pengaruh terhadap suatu kondisi.

Jenis penelitian ini digunakan karena dapat menyesuaikan metode kualitatif lebih mudah apabila berhadapan dengan kenyataankenyataan. ${ }^{11}$

\section{HASIL PENELITIAN DAN PEMBAHASAN}

\subsection{Sistem Akad pada BPJS Kesehatan Mandiri di Kota Parepare}

Akad berarti perjanjian (آلَهَهُدُ), karena pelaku akad saling berjanji untuk mematuhi dan melaksanakan apa-apa yang telah dibuat dan disepakati bersama. ${ }^{12}$ Dilihat dari niat (motif pelakunya) akad terdiri dari akad mu'awadah (bisnis) dan akad tabarru'(kebajikan). Jenis-jenis akad pada BPJS Kesehatan yaitu secara umum akad yang dilakukan ketika mendaftar sebagai peserta BPJS Kesehatan adalah akad antara PesertaIndividu $^{13}$ dengan Peserta-Kolektif ${ }^{14}$ yang diwakili BPJS Kesehatan adalah akad hibah ${ }^{15}$ dalam rangka saling menolong sesama peserta (ta'awun). Artinya akad yang terjadi ketika mendaftarkan diri sebagai pesı BPJS Kesehatan adalah akad antara seorang peserta (Peserta-Individu) dengan seluruh peserta yang telah terdaftar sebelumnya (PesertaKolektif) yang diwakili BPJS 
Kesehatan. Adapun jenis akadnya adalah akad hibah dalam rangka saling menolong sesama peserta (ta'awun) berdasarkan prinsip BPJS Kesehatan yaitu gotong royong.

Setelah melakukan akad hibah, maka diikuti beberapa akad-akad lainnya yang berhubungan dengan pengelolaan BPJS Kesehatan seperti:

a..Akad antara Peserta-Kolektif dengan BPJS Kesehatan adalah akad wakalah atau akad wakalah bil ujrah. ${ }^{16}$ Akad wakalah atau wakalah bil ujrah dapat mencakup pemberian kuasa untuk: kegiatan administrasi, pengelolaan portofolio risiko, investasi/ pengembangan Dana Jaminan Sosial (DJS), pembayaran klaim (dari BPJS ke faskes), dan pemasaran (promosi)/ sosialisasi.

b. Akad antara BPJS Kesehatan dengan pihak lain dalam rangka pengembangan dana jaminan sosial kesehatan adalah akad mu'awadhat ${ }^{17}$, baik dalam bentuk jual-beli, ijarah, maupun akad yang berbasis bagi hasil. Dalam hal ini yang dimaksud adalah investasi dana jaminan sosial.

c. Akad antara Pemerintah dengan
BPJS Kesehatan sebagai wakil perserta kolektif adalah akad hibah untuk menanggulangi dana jaminan sosial kesehatan yang bernilai negatif, atau akad $\operatorname{qard}^{18}$ apabila pemerintah belum memiliki anggaran khusus.

d. Akad antara BPJS Kesehatan dengan peserta-kolektif adalah akad kafalah $^{19}$

atau akad qardh untuk menanggulangi Dana Jaminan Sosial Kesehatan yang bernilai negatif.

e. Akad antara Pemerintah dengan BPJS Kesehatan sebagai wakil pesertakolektif adalah akad kafalah atau qardh dalam hal BPJS Kesehatan tidak dapat memberikan talangan, atau dapat memberikan talangan namun tidak mencukupi untuk menanggulangi kesulitan likuiditas aset Dana Jaminan Kesehatan.

f. Akad antara BPJS Kesehatan dengan Faskes adalah akad ijarah ${ }^{20}$.

Akad-akad tersebut didasarkan pada ketentuan akad dan personalia hukum Fatwa Dewan Syari'ah Nasional Nomor 98/DSNMUI/XII/2015 Tentang Pedoman Penyelenggaraan Jaminan Sosial 
293 | Diktum: Jurnal Syari'ah dan Hukum, Volume 16, Nomor 2 Desember 2018 : 284 - 306

Kesehatan Syariah.

Diantara akad-akad yang dilakukan oleh BPJS Kesehatan Kota Parepare, akad yang paling sering dilakukan adalah akad wakalah yaitu akad perwakilan dari peserta kepada BPJS Kesehatan. Abu Hanifah berpendapat bahwa wakil tersebut boleh menjual (mengelola) sebagaimana kehendak wakil itu sendiri. Menurut pandangan Mazhab Hanafi bila yang mewakili menyalahi aturan yang telah disepakati ketika akad, penyimpangan tersebut dapat merugikan pihak yang mewakilkan, maka tindakan tersebut tergantung pada kerelaan orang yang mewakilkan, jika yang mewakilkan membolehkannya maka menjadi sah, bila tidak meridhainya maka menjadi batal. Akan tetapi menurut Mazhab Syafi'i bila yang mewakili menyalahi aturan yang telah disepakati ketika akad, penyimpangan tersebut dapat merugikan pihak yang mewakilkan, maka tindakan tersebut batil. ${ }^{21}$

Berdasarkan dengan jenis-jenis akad yang digunakan dalam pengelolaan BPJS Kesehatan tersebut, sudah sesuai dengan jenis-jenis akad yang diatur dalam hukum ekonomi Islam dimana akad-akad tersebut termasuk dalam bagian dari akad tabarru' (tolong-menolong) yang sesuai dengan prinsip dari BPJS Kesehatan yaitu prinsip gotong royong. Manusia akan selalu membutuhkan dan dibutuhkan oleh orang lain. Islam sangat menekankan arti penting saling tolong menolong (ta'awun) dan saling memikul (takaful), karena memang secara prinsip, konstruksi sosial dalam Islam harus bersifat saling menguatkan antara satu dengan lainnya. ${ }^{22}$ Dengan jelasnya jenis-jenis akad yang diterapkan dalam pengelolaan BPJS Kesehatan, maka akad BPJS Kesehatan mandiri di Kota Parepare terhindar dari unsur gharar $^{23}$. Sehingga hukum akad BPJS Kesehatan adalah boleh sebagaimana dalam kaidah muamalah:

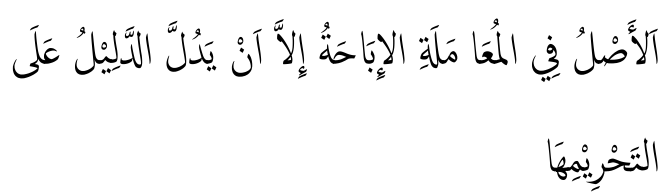

Artinya: 
Hukum asal dalam semua

bentuk muamalah adalah

kebolehan dilakukan kecuali

ada dalil yang

mengharamakannya. ${ }^{24}$

Berdasarkan kaidah muamalah di atas maka selama tidak ada dalil yang menyatakan keharaman akad yang digunakan dalam pengelolaan BPJS Kesehatan, maka hukum dari akad BPJS Kesehatan itu adalah mubah.

\subsubsection{Dasar Hukum Kepesertaan dan} Peserta BPJS Kesehatan Mandiri

Peserta adalah setiap orang termasuk orang asing yang bekerja paling singkat 6 (enam) bulan di Indonesia, yang telah membayar iuran. $^{25}$

Dasar hukum kepesertaan BPJS Kesehatan bukan PBI Jaminan Kesehatan atau yang biasa dikenal dengan peserta BPJS Kesehatan Mandiri terdapat dalam Peraturan Presiden Republik Indonesia Nomor 19 Tahun 2016 Tentang Perubahan Kedua atas Peraturan Presiden Nomor 12 Tahun 2013 Tentang Jaminan Kesehatan Pasal 4 dimana Peserta bukan PBI Jaminan Kesehatan terdiri atas:

a. Pekerja Penerima Upah dan anggota keluarganya;

b. Pekerja Bukan Penerima Upah dan anggota keluarganya;

c. Bukan Pekerja dan anggota keluarganya.

Dalam Pasal 4 ayat

Peraturan Presiden Republik Indonesia Nomor 19 Tahun 2016 Tentang Perubahan Kedua atas Peraturan Presiden Nomor 12 Tahun 2013 Tentang Jaminan Kesehatan, peserta pekerja penerima upah terdiri atas:

1). Pegawai Negeri Sipil; 2). Anggota TNI; 3). Anggota Polri; 4). Pejabat Negara; 5).Pemimpin dan anggota Dewan Perwakilan Rakyat Daerah ; 6).Pegawai Pemerintah Non Pegawai Negeri; 7). Pegawai swasta; dan 8). Pekerja yang tidak termasuk diatas yang menerima Upah.

Dalam Pasal 4 ayat

Peraturan Presiden Republik Indonesia Nomor 19 Tahun 2016 Tentang Perubahan Kedua atas Peraturan Presiden Nomor 12 Tahun 2013 Tentang Jaminan Kesehatan, pekerja 
295 | Diktum: Jurnal Syari'ah dan Hukum, Volume 16, Nomor 2 Desember 2018 : 284 - 306

bukan penerima upah terdiri atas:

a.Pekerja di luar hubungan kerja atau

Pekerja mandiri; dan

b.Pekerja yang tidak termasuk Pekerja

di luar hubungan kerja atau Pekerja mandiri yang bukan penerima Upah.

Persyaratan untuk menjadi peserta BPJS Kesehatan Mandiri cukup mudah, asalkan dapat memenuhi salah satu kriteria yang telah diuaraikan sebelumnya, kemudian melakukan pendaftaran peserta. Pendaftaran peserta BPJS Kesehatan dapat dilakukan secara online maupun offline di kantor BPJS kesehatan. Tersedia beberapa jenis keanggotaan BPJS yaitu peserta BPJS mandiri, peserta BPJS Perusahaan (PPU) dan peserta Penerima Bantuan Iuran (PBI).

Tersedia 3 jenis kelas, ada kelas

1 dengan iuran peserta Rp.80.000,- per bulan, kelas 2 dengan iuran peserta Rp.51.000,- per bulan, dan kelas 3 dengan iuran peserta Rp.25.500,- per bulan. Pembayaran iuran dilakukan setiap bulan dan dibayar sebelum tanggal 10 , jika peserta terlambat maka kepesertaannya akan di nonaktifkan. Untuk pendaftaran menjadi peserta BPJS Kesehatan Mandiri calon peserta perlu mempersiapkan beberapa syarat pendaftaran yakni:

1). Kartu Keluarga asli, 2). Fotocopy Kartu Keluarga, 3). Fotocopy Kartu Kartu Tanda Penduduk calon peserta, 4). Pasfoto $3 \times 4$ warna, 5). Buku tabungan jika pilih kelas I atau II, 6). Mengisi formulir dan 7). Dalam 1 Kartu Keluarga (KK) wajib daftar untuk keluarga inti dan memilih kelas yg sama.

Setelah mendaftaran maka calon peserta akan mendapatkan Virtual Account Number untuk melakukan pembayaran pertama dan status kepesertaan akan aktif. Pembayaran iuran pertama dapat dilakukan setelah 14 hari sejak pendaftaran, begitu juga dengan keaktifan keanggotaan peserta bisa digunakan untuk berobat jika sudah membayar iuran pertama. ${ }^{26}$

Selain pendaftaran secara langsung ke loket BPJS Kesehatan, dapat pula dilakukan pendaftaran 
secara online. Untuk pendaftaran secara online terdapat syarat dan ketentuan penggunaan Website Layanan Pendaftaran BPJS Kesehatan.

\subsection{Mekanisme Pengumpulan \\ Iuran pada BPJS Kesehatan Mandiri di Kota Parepare}

Iuran merupakan sejumlah uang yang dibayar secara teratur oleh peserta, pemberi kerja, dan/atau Pemerintah untuk jaminan kesehatan. ${ }^{27}$ Khusus untuk peserta mandiri, iurannya dibayar sendiri oleh peserta secara keseluruhan atau dibayarkan sebagian oleh pemberi kerja. Pembayaran iuran BPJS Kesehatan sekarang menggunakan sistem pembayaran secara kolektif atau pembayaran satu VA (Virtual Account).

Beberapa pembagian jumlah iuran peserta BPJS Kesehatan Mandiri/ peserta bukan Penerima Bantuan Iuran: a.Iuran bagi Peserta Pekerja Penerima Upah yang bekerja pada Lembaga Pemerintahan terdiri dari Pegawai Negeri Sipil, anggota TNI, anggota Polri, pejabat negara, dan pegawai pemerintah non pegawai negeri sebesar
5\% (lima persen) dari Gaji atau Upah per bulan dengan ketentuan : 3\% (tiga persen) dibayar oleh pemberi kerja dan 2\% (dua persen) dibayar oleh peserta.

b.Iuran bagi Peserta Pekerja Penerima Upah yang bekerja di BUMN, BUMD dan Swasta sebesar 5\% ( lima persen) dari Gaji atau Upah per bulan dengan ketentuan : 4\% (empat persen) dibayar oleh Pemberi Kerja dan 1\% (satu persen) dibayar oleh Peserta.

c.Iuran untuk keluarga tambahan Pekerja Penerima Upah yang terdiri dari anak ke 4 dan seterusnya, ayah, ibu dan mertua, besaran iuran sebesar $1 \%$ (satu persen) dari dari gaji atau upah per orang per bulan, selebihnya dibayar oleh pekerja penerima upah.

d.Iuran bagi kerabat lain dari pekerja penerima upah (seperti saudara kandung/ ipar, asisten rumah tangga, dll); peserta pekerja bukan penerima upah serta iuran peserta bukan pekerja adalah sebesar:

1).Sebesar Rp. 25.500,- (dua puluh lima ribu lima ratus rupiah) per orang per bulan dengan manfaat pelayanan di ruang perawatan Kelas III.

2).Sebesar Rp. 51.000,- (lima puluh 
297 | Diktum: Jurnal Syari'ah dan Hukum, Volume 16, Nomor 2 Desember 2018 : 284 - 306

satu ribu rupiah) per orang per bulan dengan manfaat pelayanan di ruang perawatan Kelas II.

3).Sebesar Rp. 80.000,- (delapan puluh ribu rupiah) per orang per bulan dengan manfaat pelayanan di ruang perawatan Kelas I.

4).Iuran Jaminan Kesehatan bagi Veteran, Perintis Kemerdekaan, dan calon peserta, duda, atau anak yatim piatu dari Veteran atau Perintis Kemerdekaan, iurannya ditetapkan sebesar 5\% (lima persen) dari 45\% (empat puluh lima persen) gaji pokok Pegawai Negeri Sipil golongan ruang III/a dengan masa kerja 14 (empat belas) tahun per bulan, dibayar oleh Pemerintah.

5).Pembayaran iuran paling lambat tanggal 10 (sepuluh) setiap bulan. ${ }^{28}$

Jumlah iuran peserta BPJS Kesehatan sewaktu-waktu akan berubah sesuai dengan peraturan yang mengaturnya, seperti sebelumnya jumlah iuran bagi kelas I sebesar Rp. 59.500,- dan untuk peserta kelas II peserta BPJS Mandiri adalah Rp. 42.500 ,- besaran jumlah iuran ini diatur dalam Peraturan Presiden Republik Indonesia Nomor 111 Tahun 2013 Tentang Perubahan Atas Peraturan Presiden Nomor 12 Tahun 2013 Tentang Jaminan Kesehatan, yang hingga sekarang sudah mengalami tiga kali perubahan dengan peraturan terakhir hingga sekarang yaitu Peraturan Presiden Republik Indonesia Nomor 28 Tahun 2016 Tentang Perubahan Ketiga atas Peraturan Presiden Nomor 12 Tahun 2013 Tentang Jaminan Kesehatan.

Berikut adalah beberapa tempat pembayaran iuran BPJS Kesehatan yang bisa calon peserta gunakan untuk membayar iuran Bulanan BPJS calon peserta antara lain:

1). ATM Bank, 2). Di Minimarket / Alfamart dan Indomart, 3). Di Kantor Pos, 4).Melalui Autodebet bank dan 5). Melalui SMS Banking

\subsection{Mutu jaminan BPJS Kesehatan di Kota Parepare terhadap pelayanan kesehatan bagi peserta BPJS Kesehatan Mandiri.}


Fasilitas Kesehatan BPJS maka dokter faskes tingkat 2 akan Kesehatan di Kota Parepare adalah segala sarana dan prasarana alat atau tempat yang dapat menunjang kesehatan atau yang dapat digunakan untuk menyelenggarakan pelayanan kesehatan, baik promotif, preventif, kuratif maupun rehabilitatif yang dilakukan oleh pemerintah, pemerintah daerah dan atau masyarakat.

Pada sistem BPJS Kesehatan, fasilitas kesehatan ini dikategorikan menjadi beberapa kategori (faskes tingkat 1, 2 dan 3), pengkategorian ini dikarenakan sistem BPJS menggunakan sistem pelayanan berjenjang, artinya ketika peserta BPJS Kesehatan ingin berobat guna mendapatkan layanan kesehatan yang ditanggung oleh BPJS Kesehatan, maka fasilitas kesehatan yang harus pertama kali dikunjungi adalah fasilitas kesehatan tingkat 1, jika di faskes tingkat 1 , tidak memungkinkan untuk dilayani maka dokter faskes tingkat 1 akan merujuk ke faskes tingkat 2, dan jika di faskes tingkat 2 masih tidak memungkinkan untuk dilayani karena sarana dan prasarana kurang memadai merujuk ke fasilitas kesehatan tingkat 3.

Pembagian tingkatan fasilitas kesehatan ini berdasarkan tugas BPJS Kesehatan mengacu pada pasal 24 ayat (3) Undang-Undang Sistem Jaminan Sosial Nasional Nomor 40 Tahun 2004 untuk mengembangkan sistem yang efektif dan efisien. Apa yang memang bisa dilayani di Rumah Sakit tipe bawah, tidak boleh dirujuk ke tipe di atasnya. Dasarnya adalah kemampuan layanan di tiap-tiap tipe Rumah Sakit yang tersedia. Karena itu BPJS Kesehatan melakukan kredensialing salah satunya memetakan apa saja kemampuan layanan pada tiap-tiap fasilitas kesehatan.

Perbedaan fasilitas kesehatan tingkat 1, 2 dan 3 BPJS Kesehatan terletak pada jenis dan jumlah layanan medik juga spesialis dan kelengkapan sarana dan prasarana yang dimiliki oleh fasilitas kesehatan tersebut. Peserta BPJS Kesehatan sangat merasa puas dan tertolong dengan adanya program JKN yang diselenggarakan oleh BPJS Kesehatan khususnya di 
299 | Diktum: Jurnal Syari'ah dan Hukum, Volume 16, Nomor 2 Desember 2018 : 284 - 306

Kota Parepare, dapat dikatakan bahwa program ini patut untuk dipertahankan dan ditingkatkan lagi, karena tujuannya bukan mengejar profit/ keuntungan, akan tetapi memiliki prinsip gotong royong, saling tolong menolong, orang sehat menolong orang yang sakit, orang kaya menolong orang yang miskin. Prinsip ini sebagaimana firman Allah SWT dalam Q.S. Al-Maidah/5:2 sebagai berikut:

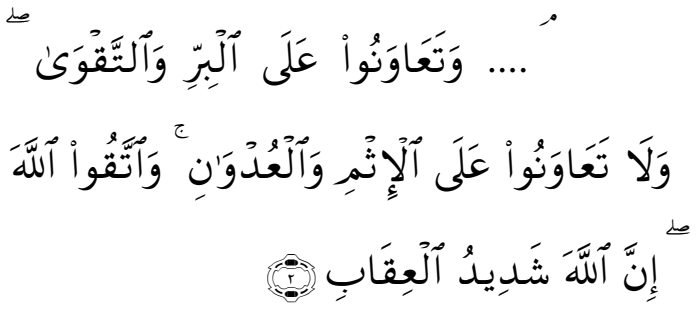

Terjemahnya:

....Dan tolong-menolonglah kamu dalam (mengerjakan) kebajikan dan takwa, dan jangan tolong-menolong dalam berbuat dosa dan pelanggaran. dan bertakwalah kamu kepada Allah, Sesungguhnya Allah amat berat siksa-Nya.

BPJS Kesehatan Mandiri memiliki kemaslahatan lebih banyak daripada mudharatnya, dan tujuan dari BPJS Kesehatan adalah untuk kemaslahatan umat, maka hukum BPJS Kesehatan Mandiri adalah boleh, berdasarkan kaidah fikih khusus di bidang siyasah.
Sesuai dengan kaidah fikih tersebut maka berlakulah esensi dari maqashid al-syahri'ah yaitu jalb almashalih wa daf'u al-mafasid (mengerjakan kemaslahatan dan meninggalkan kerusakan). Karena kemaslahatan mutu jaminan BPJS Kesehatan mandiri bagi pelayanan kesehatan lebih banyak yang dirasakan peserta daripada mudharatnya, maka hukum mutu jaminan BPJS Kesehatan mandiri ini adalah boleh.

Jadi bagi masyarakat Kota Parepare yang ingin mendaftarkan diri sebagai peserta BPJS Kesehatan Mandiri tidak perlu ragu lagi akan mutu jaminan BPJS Kesehatan mandiri di Kota Parepare.

Berdasarkan Fatwa Dewan Syari'ah Nasional Majelis Ulama Indonesia Nomor 98/DSNMUI/XII/2015 Tentang Pedoman Penyelenggaraan Jaminan Sosial Kesehatan Syariah, BPJS Kesehatan sebagai wakil Peserta-Kolektif memiliki kewajiban antara lain memberikan informasi yang jelas kepada Peserta Individu terkait jumlah 
iuran dan manfaat atau cakupan layanan fasilitas kesehatan yang ditanggung (jenis layanan, tingkat layanan, tenaga medis, penunjang diagnostik, obat, bentuk-bentuk terapi, dan biaya-biaya layanan kesehatan lainnya); bertanggungjawab untuk mengupayakan agar besaran pembayaran imbalan dan membayarnya kepada fasilitas layanan kesehatan (Faskes) melalui sistem yang adil dan transparan; menunaikan kewajibannya dengan baik kepada Faskes sesuai perjanjian; Faskes wajib memberikan layanan kesehatan kepada Peserta-Individu sesuai prinsip-prinsip syariah serta peraturan perundangundangan yang berlaku; wajib menolong pasien dan dilarang menolak dan/ atau mengabaikannya.

\section{PENUTUP}

\subsection{Kesimpulan}

5.1.1 Sistem akad pada BPJS Kesehatan Mandiri di Kota Parepare yang diterapkan dan dilakukan peserta BPJS Kesehatan Mandiri adalah akad yang dilakukan saling setuju antara kedua belah pihak.
Selain akad tersebut, ada juga akad-akad yang dilakukan oleh BPJS Kesehatan kepada pemerintah dan Pihak ketiga. Dengan jelasnya jenis-jenis akad tersebut seperti akad ta'awun, kafalah, dan sebagainya, maka akad BPJS Kesehatan terhindar dari unsur gharar. Sehingga hukum akad BPJS Kesehatan Mandiri adalah boleh.

5.1.2 Mekanisme pengumpulan iuran pada BPJS Kesehatan Mandiri di Kota Parepare dilakukan sesuai dengan prosedur yang diberlakukan di BPJS Kesehatan Parepare. Akan tetapi mekanisme pembayaran iuran pada BPJS Kesehatan di Kota Parepare dengan cara pembayaran iuran secara kolektif dalam satu keluarga dengan pilihan kelas yang harus sama, belum sesuai dengan prinsip ekonomi Islam karena memberatkan peserta, namun berdasarkan kaidah fikih yang digunakan lebih baik tetap 
301 | Diktum: Jurnal Syari'ah dan Hukum, Volume 16, Nomor 2 Desember 2018 : 284 - 306

menjadi peserta BPJS Kesehatan mandiri di Kota Parepare, Kesehatan mandiri. karena setelah diteliti ternyata sistem

5.1.3 Mutu jaminan BPJS Kesehatan Mandiri di Kota Parepare terhadap pelayanan kesehatan bagi peserta BPJS Kesehatan mandiri sudah baik dilihat dari kepuasan peserta terhadap pelayanannya. Sehingga berlaku esensi dari maqashid al-syahri'ah yaitu jalb almashalih wa daf'u al-mafasid (mengerjakan kemaslahatan dan meninggalkan kerusakan). ${ }^{29} \quad$ Karena kemaslahatannya lebih banyak yang dirasakan peserta daripada mudharatnya, maka hukum mutu jaminan BPJS Kesehatan mandiri ini adalah boleh.

\subsection{Saran}

Adapun saran penulis dalam penulisan skripsi ini adalah sebagai umat muslim yang ingin mendaftarkan diri sebagai peserta BPJS Kesehatan Mandiri tidak perlu ragu lagi dan khawatir akan mutu jaminan BPJS pengelolaan BPJS Kesehatan Mandiri di Kota Parepare sudah sesuai prinsipprinsip ekonomi syariah, kecuali mengenai sistem pengumpulan iuran dalam hal mekanisme pembayaran iurannya belum sesuai dengan hukum ekonomi Islam karena sebagian besar memberatkan peserta dalam membayar iurannya, akan tetapi dibandingkan ketika tidak menjadi peserta BPJS Kesehatan akan lebih banyak biaya pengobatan yang digunakan ketika sakit. Dan bagi peserta seharusnya memahami terlebih dahulu peraturanperaturan yang mengatur mengenai pengelolaan BPJS Kesehatan serta mematuhi ketentuan dan prosedur pelayanan yang diberlakukan di masing-masing fasilitas kesehatan. 


\section{DAFTAR PUSTAKA}

\section{Bibliography}

Abdulahanaa. 2014. Kaidah-kaidah Keabsahan Multi Akad (Hybrid Contract). Yogyakarta: TrustMedia.

Ali, Zainuddin. 2011. Metode Penelitian Hukum. Jakarta: Sinar Grafika.

Antonio, Muhammad Syafi'i. 2001. Bank Syariah dari Teori ke Praktik. Jakarta: Gema Insani Press.

Arifin,Johar. 2016. Substansi Akad Dalam Transaksi Syariah, Al Amwal http://www.syekhnurjati.ac.id/j urnal/index.php/amwal/article/v iew/256 (diakses 28 Februari 2018)

Audit dan Modernisasi BPJS Kesehatan. 2016. Majalah Parlemantaria, Edisi EDISI 135 TH. XLVI. Jakarta: Parlementaria. http://m135-2016.pdf (diakses 7 Juni 2018).

Basrowi dan Suwandi. 2008. Memahami Penelitian Kualitatif. Jakarta: Rineka Cipta.

BPJS Kesehatan. 2014. "Peraturan Badan Penyelenggara Jaminan Sosial Kesehatan Nomor 1 Tahun $2014 \quad$ Tentang Penyelenggaraan Jaminan Kesehatan". http://Peraturan BPJS No 1 Tahun 2014_326_1.pdf (diakses 30 Mei 2018).
Bungin, Burhan. 2012. Analisis Data Penelitian Kualitatif. Jakarta: PT RajaGrafindo Persada.

Damin,Sudarman. 2012. Menjadi Peneliti Kualitatif: Ancangan Metodologi, Presentasi, dan Publikasi Hasil Penelitian untuk Mahasiswa dan Peneliti Pemula Bidang Ilmu-ilmu Sosial, Pendidikan, dan Humaniora. Bandung: CV Pustaka Setia.

Departemen Agama RI. 1998. Alqur'an dan Terjemahnya dengan Transliterasi Arab. Semarang: PT. Karya Toha Putra Semarang.

Djazuli, A. 2006. Kaidah-Kaidah Fikih : Kaidah-Kaidah Hukum Islam dalam Menyelesaikan MasalahMasalah Praktis. Jakarta: Kencana Media Group.

Fauzia, Ika Yunia dan Abdul Kadir Riyadi. 2014. Prinsip Dasar Ekonomi Islam Persfektif Maqasid al-Syari'ah. Jakarta: Kencana.

Ikhsan, Muhammad. 2016. "Bab II Landasan Teori Premi, Klaim, dan Pertumbuhan Aset". Universitas Islam: Bandung. http://repository.unisba.ac.id...0 6bab2_Muhammad\%20Ikhsan 1001021002.pdf (diakses 7 Juni 2016).

Kartini, Indira. 2016. Operasionalisasi Badan Penyelenggara Jaminan Kesehatan (BPJS). Tesis Magister; Program Pascasarjana UIN Sunan Kalijaga: Yogyakarta. http://digilib.uinsuka.ac.id/21845/1/142031000s _BAB-I_IV-atau-V_DAFTAR- 
303 | Diktum: Jurnal Syari'ah dan Hukum, Volume 16, Nomor 2 Desember 2018 : 284 - 306

PUSTAKA.pdf. (diakses 12 Februari 2017).

Kementrian Kesehatan RI. "Buku Pegangan Sosialisasi Jaminan Kesehatan Nasional (JKN) dalam sistem Jaminan Sosial". http://www.depkes.go.id/resour ces/.../jkn/buku-pegangansosialisasi-jkn.pdf (diakses 1 April 2016).

Majlis Taqarrub Ila Allah. Hukum Riba dan Bunga Bank. https://alqandaly.wordpress.co m/2013/11/04/hukum-riba-danbunga-bank/ home (diakses 8 April 2016).

Majelis Ulama Indonesia. 2015. "Hasil Ijtima' Ulama Komisi Fatwa se-Indonesia V Tahun 2015. http:// MU-Hasil-Ijtima-UlamaV-tahun-2015.pdf (diakses 7 Maret 2016).

Manan, H Abdul. 2012. Hukum Ekonomi Syariah: Dalam Perspektif Kewenangan Peradilan Agama. Jakarta: Kencana Prenadamedia Group.

Ma'rufah, Nur. 2009. Sistem Pengelolaan Dana Yayasan Panti Asuhan Taman Thoyyibah Sedati Gede Siduarjo. Skripsi Sarjana: Fakultas Dakwah UIN Sunan Ampel Surabaya: Surabaya. http://digilib.uinsby.ac.id77673 bab\%202.pdf (7 Juni 2016).

Moleong, Lexy J. 2010. Metodologi Penelitian Kualitatif. Bandung: PT Remaja Rosdakarya.

Muhamad. 2008. Metodologi Penelitian Ekonomi Islam
Pendekatan Kuantitatif Jakarta: Raja Grafindo Persada.

Peraturan Menteri Kesehatan Republik Indonesia Nomor 52 Tahun 2016 Tentang Standar Tarif Pelayanan Kesehatan dalam Penyelenggaraan Program Jaminan Kesehatan.

Pusat Pengkajian Hukum Islam dan Masyarakat Madani. 2009. Kompilasi Hukum Ekonomi Syariah. Jakarta: Kencana.

Republik Indonesia. 2016. "Peraturan Presiden Republik Indonesia Nomor 19 Tahun 2016 Tentang Perubahan Kedua Atas Peraturan Presiden Nomor 12 Tahun 2013 Tentang Jaminan Kesehatan". http://PERPRES No. 19 Th 2016 ttg Jaminan Kesehatan.pdf (diakses 7 Juni 2016).

Rusdi, Muhammad Ali. "Maslahat sebagai Metode Ijtihad dan Tujuan Utama Hukum Islam." DIKTUM: Jurnal Syariah dan Hukum 15.2 (2017): 151-168.

Rokhaningsih. 2008. "Tinjauan Hukum Islam terhadap Akad Tabarru' di PT. Asuransi Takaful Keluarga Semarang”. Skripsi Sarjana; Fakultas Syariah IAIN Walisongo: Semarang. http://jtptiain-gdl-rokhanings4035-1-2103104.pdf (diakses 7 Maret 2016).

Situs Resmi BPJS Kesehatan. http://www.bpjskesehatan.go.id/. (diakses 30 Desember 2016). 
Situs Resmi Kota Parepare, http://www.pareparekota.go.id/. (diakses 29 Desember 2016).

Suhendi, Hendi. 2002. Fiqh Muamalah. Jakarta: Raja Grafindo.

Sula, Muhammad Syakir. 2004. Asuransi Syariah (life and general): Konsep dan Sistem Operasional. Jakarta: Gema Insani Press.

Syafei, Rachmat. 2001. Fiqh Muamalah. Bandung: Pustaka Setia.

Tim Pustaka Yustisia. 2014. Panduan Resmi Memperoleh Jaminan Kesehatan dari BPJS. Visi Media.

https://books.google.com/books (diakses 18 Januari 2017).

Triyanta, Agus. 2012. Hukum Ekonomi Islam dari Politik Hukum Ekonomi Islam sampai Pranata Ekonomi Syariah. Yogyakarta: FH UII Press.

Zainuddin, A dan Muhammad Jamhari. 1999. Al-Islam 2 Muamalah dan Akhlak. Bandung: Pustaka Setia.

Zulkahfi. 2014. Jaminan Kesehatan Nasional (JKN) Perfektif Hukum Islam. Skripsi Sarjana; Fakultas Syari'ah dan Hukum UIN Sunan Kalijaga: Yogyakarta. http://digilib.uinsuka.ac.id/.../2/10380002_babi_iv-atau-v_daftar-pustaka.pdf 
305 | Diktum: Jurnal Syari'ah dan Hukum, Volume 16, Nomor 2 Desember 2018 : 284 - 306

\section{Catatan Akhir}

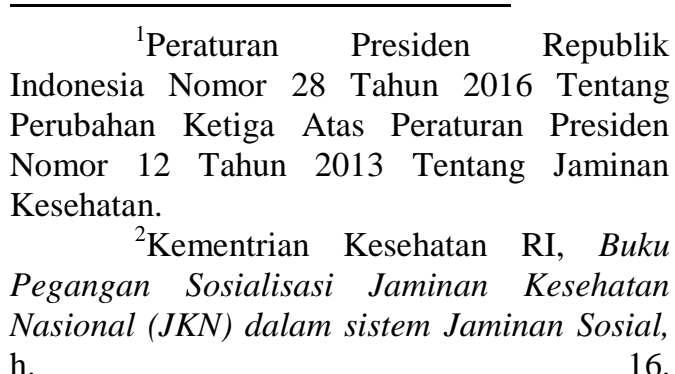

http://www.depkes.go.id/resources/.../jkn/buku -pegangan-sosialisasi-jkn.pdf

${ }^{3}$ Zulkahfi, "Jaminan Kesehatan

Nasional (JKN) Perfektif Hukum Islam" (Skripsi Sarjana; Fakultas Syari'ah dan Hukum UIN Sunan Kalijaga: Yogyakarta, 2014), h. 2. http://digilib.uin-

suka.ac.id/.../2/10380002_bab-i_iv-atauv daftar-pustaka.pdf (31 Maret 2016).

${ }^{4}$ Peraturan Presiden Republik Indonesia Nomor 19 Tahun 2016 Tentang Perubahan Kedua Atas Peraturan Presiden Nomor 12 Tahun 2013 Tentang Jaminan Kesehatan Pasal 16 ayat (3), h. 13. http://PERPRES No. 19 Th 2016 ttg Jaminan Kesehatan.pdf (7 Juni 2016).

${ }^{5}$ Abdulahanaa, Kaidah-kaidah Keabsahan Multi Akad (Hybrid Contract) (Yogyakarta: TrustMedia, 2014), h. 25.

${ }^{6}$ Abdulahanaa, Kaidah-kaidah Keabsahan Multi Akad (Hybrid Contract), h. 26.

${ }^{7}$ Muhammad Syakir Sula, Asuransi Syariah (life and general): konsep dan sistem operasional (Jakarta: Gema Insani Press, 2004), h. 38

${ }^{8}$ Abdulahanaa, Kaidah-kaidah Keabsahan Multi Akad (Hybrid Contract), h. 27.

${ }^{9}$ BPJS Kesehatan, "Peraturan Badan Penyelenggara Jaminan Sosial Kesehatan Nomor 1 Tahun $2014 \quad$ Tentang Penyelenggaraan Jaminan Kesehatan", Pasal 1 ayat 4. http://Peraturan BPJS No 1 Tahun 2014_326_1.pdf (30 Mei 2016).

${ }^{10}$ Muhammad Syakir Sula, Asuransi Syariah (Life and General): Konsep dan Sistem Operasional (Jakarta: Gema Insani Press, 2004), h. 28.
${ }^{11}$ Lexy J Moleong, Metodologi Penelitian Kualitatif (Bandung: PT Remaja Rosdakarya, 2010), h. 5

${ }^{12}$ Abdulahanaa,

Kaidah-kaidah Keabsahan Multi Akad (Hybrid Contract), h. 26.

${ }^{13}$ Peserta-Individu adalah setiap orang yang membayar iuran, baik membayar sendiri, dibayarkan sebagian atau seluruhnya oleh pemberi kerja, ataupun dibayarkan oleh Negara, guna mengikuti program jaminan sosial kesehatan sesuai peraturan perundangundangan yang berlaku.

${ }^{14}$ Peserta-Kolektif adalah keseluruhan Peserta Individu yang terhimpun dalam kumpulan peserta jaminan sosial kesehatan.

${ }^{15}$ Akad hibah yaitu pemberian sejumlah dana dari Peserta-Individu kepada PesertaKolektif, dari Pemerintah kepada Penerima Bantuan Iuran (PBI), dan/atau dari Pemerintah kepada BPJS Kesehatan sebagai wakil Perserta Kolektif untuk menanggulangi Dana Jaminan Sosial Kesehatan yang bernilai negatif.

${ }^{16}$ Akad Wakalah atau Wakalah bi alUjrah adalah akad antara Peserta-Kolektif dengan BPJS Kesehatan untuk kegiatan administrasi dan kegiatan lainnya sesuai dengan prinsip-prinsip syariah.

${ }^{17}$ Akad mu'awadhat adalah akad usaha antara BPJS Kesehatan sebagai wakil Peserta Kolektif dengan Pihak ketiga untuk mengembangkan Dana Jaminan Sosial Kesehatan.

${ }^{18} \mathrm{Akad}$ qardh adalah pinjaman dari BPJS Kesehatan kepada Peserta Kolektif untuk menanggulangi kesulitan likuiditas Dana Jaminan Sosial Kesehatan atau pinjaman dari pemerintah kepada Peserta Kolektif untuk menanggulangi kesulitan likuiditas Dana Jaminan Sosial Kesehatan apabila pemerintah belum memiliki anggaran khusus.

${ }^{19}$ Akad Kafalah adalah akad antara BPJS Kesehatan dengan Peserta Kolektif untuk menanggulangi Dana Jaminan Sosial Kesehatan yang bernilai negatif.

${ }^{20}$ Akad Ijarah adalah akad antara BPJS Kesehatan sebagai wakil Peserta Kolektif dengan Faskes untuk melakukan pelayanan kesehatan.

${ }^{21}$ Hendi Suhendi, Fiqh Muamalah, h. 
236.

${ }^{22}$ Agus Triyanta, Hukum Ekonomi Islam dari Politik Hukum Ekonomi Islam sampai Pranata Ekonomi Syariah (Yogyakarta: FH UII Press, 2012), h. 48-49.

${ }^{23}$ Gharar yaitu Ketidakpastian akibat yang timbul dari suatu akad.

${ }^{24}$ A Djazuli, Kaidah-Kaidah Fikih : Kaidah-Kaidah Hukum Islam dalam Menyelesaikan Masalah-Masalah Praktis, h. 52.

${ }^{25}$ Presiden Republik Indonesia, Peraturan Presiden Nomor 12 Tahun 2013 Tentang Jaminan Kesehatan Pasal 1 ayat (6).

${ }^{26}$ Benazir Ashari, Pegawai BPJS Kesehatan Kota Parepare, Sulsel, wawancara oleh penulis di Jl. Jenderal Sudirman No. 105 Parepare, 29 Desember 2016.

${ }^{27}$ Yustisia, Panduan Resmi Memperoleh Jaminan Kesehatan dari BPJS, h. 3.

${ }^{28}$ Benazir Ashari, Pegawai BPJS Kesehatan Kota Parepare, Sulsel, wawancara oleh penulis di Jl. Jenderal Sudirman No. 105 Parepare, 29 Desember 2016.

${ }^{29}$ Muhammad Ali Rusdi, "Maslahat sebagai Metode Ijtihad dan Tujuan Utama Hukum Islam." DIKTUM: Jurnal Syariah dan Hukum 15.2 (2017): 151-168. 